\title{
The Public's Knowledge and Compliance with Preventive Measures Related to COVID-19 in Turkey
}

\section{Türkiye'de Toplumun COVID-19’a Yönelik Bilgisi ve Önlemlere Uyumu}

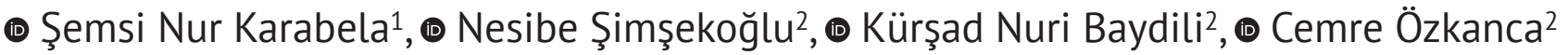 \\ ${ }^{1}$ University of Health Sciences Turkey, Bakırköy Dr. Sadi Konuk Training and Research Hospital, Clinic of Infectious Diseases and Clinical Microbiology, \\ Istanbul, Turkey \\ ${ }^{2}$ University of Health Sciences, Hamidiye Vocational School of Health Services, İstanbul, Turkey
}

Background: Coronavirus disease-2019 (COVID-19) which emerged in Wuhan City of China at the end of 2020, on March 11, 2020, was declared as a pandemic by the World Health Organization and the first case was seen in Turkey on the same date. With the declaration of the pandemic and the occurrence of the case in Turkey, information was given on the prevention of the disease through the written and visual media. This study aims to determine how the notifications are received in different target groups and to have an idea about the way to be followed for presenting information in the future epidemic diseases such as COVID-19.

Materials and Methods: This research was carried out between 14.11.2020 and 20.11.2020. A questionnaire consisting of 3 parts was used in the research and 3,094 people were included in the sample. The analysis of the data was carried out using the SPSS 25 package program. The total number of correct answers in the questions asked to the participants was accepted as the person's knowledge level of protection from COVID-19 disease. To determine the compliance levels of the participants, they were asked to score their level of compliance with the measures out of 10. Independent sample t-test and One-Way ANOVA were used to compare knowledge and prevention levels with demographic variables.

Results: It was found that the knowledge level of women, who were under 65 years old, single, with at least university education and living in a village/town, about protection from COVID-19 disease was higher than the other categories belonging to the same variables. In terms of compliance with the measures, it was determined that women, who were $36-50$ years old, married, and residing in the city had higher scores.

Conclusion: In our country, it has been determined that the level of knowledge of prevention of COVID-19 disease and the level of compliance with measures differ according to various demographic variables. In raising the awareness of societies in epidemic diseases, considering the gender, age group, marital status, education level, and place of residence of the individuals, it is thought that it is of great importance in terms of epidemic management that it is done to different masses with different methods.

Keywords: COVID-19, coronavirus, pandemic, compliance, attitude

Amaç: 2020 yılının sonlarında Çin'in Wuhan Şehrinde ortaya çıkan Koranavirüs hastalığı-2019 (COVID-19) 11 Mart 2020 Tarihinde, Dünya Sağlık Örgütü tarafından pandemi ilan edilmiştir ve aynı tarihte Türkiye'de de ilk olgu görülmüştür. Pandemi ilanı ve Türkiye'de ilk olgunun görülmesiyle birlikte yazılı ve görsel medya üzerinden hastalıktan korunma ile ilgili bilgilendirmeler yapılmıştır. Yapılan bilgilendirmelerin farklı hedef kitlelerde nasıl karşılık bulduğunu tespit etmeyi amaçlayan bu çalışmayla, COVID-19 gibi ileride ülkemizde meydana gelebilecek salgın hastalıklarda yapılacak bilgilendirmelerde nasıl bir yol izleneceği hakkında fikir sahibi olunması hedeflenmektedir.

Gereç ve Yöntemler: Bu araştırma, 14.11.2020 ile 20.11.2020 tarihleri arasında gerçekleştirilmiştir. Araştırmada 3 bölümden oluşan soru formu kullanılmıştır ve örnekleme 3.094 kişi dahil edilmiştir. Verilerin analizi SPSS 25 paket programı kullanılarak gerçekleştirilmiştir. Katıımcılara yöneltilen sorulardaki toplam doğru sayısı, kişinin COVID-19 hastalığından korunma bilgi düzeyi olarak kabul edilmiştir. Katılımcıların uyum düzeylerini belirlemek için, önlemlere uyum düzeylerini 10 üzerinden puanlamaları istenmiştir. Bilgi ve önlem düzeylerinin demografik değişkenlerle karşılaştırılmasında bağımsız örneklem t-testi ve tek yönlü ANOVA kullanılmıştır.

Address for Correspondence: Nesibe Şimşekoğlu, University of Health Sciences Turkey, University of Health Sciences, Hamidiye Vocational School of Health Services, İstanbul, Turkey

Phone: +90 5539319791 E-mail: nesibe.simsekoglu@sbu.edu.tr ORCID ID: orcid.org/0000-0002-6461-7961

Received: 29.05.2021 Accepted: 24.08.2021 
Bulgular: Kadın, 65 yaş altı, bekar, en az üniversite düzeyinde eğitim almış ve köy/kasabada yaşayan katılımcıların COVID-19 hastalığından korunmaya yönelik bilgi düzeyleri aynı değişkenlere ait diğer kategorilere göre daha yüksek bulunmuştur. Önlemlere uyum düzeyleri bakımından ise kadın, 36-50 yaş aralığında, evli ve şehirde ikamet eden katılımcıların daha yüksek puanlara sahip olduğu tespit edilmiştir.

Sonuç: Ülkemizde, COVID-19 hastalığından korunma bilgi düzeyleri ve önlemlere uyum düzeylerinin çeşitli demografik değişkenlere göre farklılık gösterdiği saptanmıştır. Salgın hastalıklarda toplumun bilinçlendirilmesinde; bireylerin cinsiyet, yaş grubu, medeni durum, eğitim düzeyi, yaşadığı yerleşim yeri gibi durumlarının göz önünde bulundurularak, farklı kitlelere farklı yöntemlerin uygulanmasının salgın yönetimi açısından büyük önem taşıdığı düşünülmektedir.

Anahtar Kelimeler: COVID-19, koronavirüs, pandemi, uyum, tutum

\section{Introduction}

The Coronavirus disease-2019 (COVID-19) epidemic, which was first seen in the city of Wuhan in China in December 2019 , soon became a serious public health problem and was declared a pandemic on March 11, 2020 (1). The first case was seen in Turkey on the same date, and by October 2021, the number of cases exceeded 2 million. Unfortunately, the disease affects individuals' daily lives, working lives, and social and economic development, and threatens their physical and mental health and even their life security (2).

The importance of preventing infection has increased together with the increasing need for intensive care and the increase occurring in the number of deaths. As in all pandemics, until an effective vaccine is made available to the public, the most effective method is to prevent the spread of the effects of COVID-19 disease. To bring the present epidemic under control in Turkey, comprehensive measures have been taken for preventing or reducing infection in vulnerable groups, primarily children, healthcare providers, and the elderly. Among the strategies used, early diagnosis, isolation, supportive treatment, guidance towards correct information sources, reporting, and contact tracing practices are included $(3,4,5,6)$. During the crisis, human knowledge and behaviors are also critical for efforts to bring the epidemic under control. In this regard, educational activities implemented to inform the public are assumed to have an important role. Scientific and reliable information given on time by health authorities will prevent the spread of incorrect information that may appear especially in visual and printed media organs $(2,7,8)$. Since the first days of the pandemic, besides the posters, brochures, and billboards prepared by the Health Ministry of the Turkish Republic, educational materials such as the COVID-19 dictionary and COVID-19 Pandemic Management and Working Directory have been presented to the public and authorities via the internet and updated. With all these practices, it is expected that the individuals who make up society will carry out their responsibilities for preventing the epidemic, implement standard protective measures aiming at hand hygiene and droplet isolation, and warn those around them about this issue $(8,9,10)$.
The public's knowledge levels, protection methods, and compliance with preventive measures related to the disease may differ regionally according to education and traditional value judgments. Determining these differences is important for increasing correct information, enabling changes in attitudes and permanent behavior, and preventing and controlling the pandemic. This study aims to define the public's knowledge levels regarding preventive measures aiming at protection from the disease and to determine and interpret their levels of compliance with these measures during the active struggle with the second wave of COVID-19, which is still in progress.

\section{Material and Methods}

\section{Research Design}

This research is a descriptive, cross-sectional type of study. Study Universe and Sample

The study universe consisted of individuals living in Turkey who used the internet and mobile phones. According to the research by the Turkish Statistical Institute (TUIK) into household information technology use, the percentage of individuals using the internet in Turkey is 79\% (11). According to the 2019 results of the TUIK address-based population system, the number of individuals who use the internet is estimated to be $63,114,643$ (12). To determine the number of individuals who needed to be included in the sample of the research, first of all, a pilot implementation was carried out. Calculations of the data obtained as a result of the pilot implementation were made by substituting them into the formula $n=\left(\sigma^{2} Z_{\alpha}^{2}\right) / d^{2} \quad$ (13). As a result of the calculations, it was concluded that it was necessary to include 2,526 individuals in the sample $\alpha=0.05 ; d=0.25 ; \sigma=6.41$ ). In the study, responses to the online questionnaire were obtained from 3,200 individuals, and 3,094 of these were considered suitable for statistical evaluation.

\section{Data Collection Tools}

A questionnaire form consisting of 3 sections was used in the study. In the first section, personal information questions consisting of 8 items are included. The second section 
concerns preventive measures with correct and incorrect options and consists of 27 items aiming at measuring participants' levels of knowledge related to the COVID-19 disease and its prevention (Ad.1). For some of the preventive measures, the correct answer is the "correct" option, while for the other preventive measures, the correct answer is the "incorrect" option. The reliability of the items intended to measure knowledge levels related to protection from the COVID-19 disease was examined with the Cronbach alpha test, and a coefficient of $\alpha=0.863$ was found. To determine content validity, the views of 5 different domain experts were obtained. For logical validity, the questions were revised according to the views of the same domain experts. The third section of the questionnaire form includes a question that can be scored on a scale from 1 to 10 and was created to determine individuals' levels of compliance with the preventive measures.

\section{Data Collection}

The research data were gathered using an online application and the responses were also recorded via the online system. The data collection was made between the dates 14.11.2020 and 20.11.2020. This period represents the second wave of the pandemic when a high number of cases were seen and the vaccine had not yet arrived in Turkey.

\section{Statistical Analysis}

The data analysis was carried out using the SPSS 25 software program. For comparisons made between scale scores and demographic variables and for comparison with scale scores of variables including two categories, independent samples t-test was used. On the other hand, for comparison with scale scores of variables including more than two categories, one-way analysis of variance (OneWay ANOVA) was used. In the case of identifying differences resulting from One-Way analysis of variance, the Bonferroni test post-hoc method was employed to determine which category or categories the differences originated from .A type I error of 0.05 was accepted in the study.

Ethical approval was obtained from the Hamidiye Scientific Research Ethics Committee for the conduct of the study (date and number: 05 May 2020; 46418926-050.03.04). The aim of the research was explained to the volunteers and informed consent for participating in the research was obtained.

\section{Results}

When the demographic data obtained from the participants were examined, it was seen that $42.8 \%(n=1,292)$ were aged $20-35$ years, $64.9 \%(n=2,009)$ were women, $65 \%$ $(n=2,010)$ were single, $49.5 \% \quad(n=1,533)$ were high school graduates, $55.7 \%(n=1,724)$ were from the Marmara Region, 61\% $(n=1,886)$ lived in big cities, and 87.4\% $(n=2,703)$ did not have any chronic diseases (Table 1).

The participants' demographic characteristics were compared regarding their knowledge scores for protection from the COVID-19 disease by using independent samples t-test and one-way analysis of variance (Table 2). As a result of the comparison, it was determined that scores were lower for participants in the group at the age of 65 years and over compared to the other age groups, for male participants

\begin{tabular}{|c|c|c|}
\hline & n & $\%$ \\
\hline \multicolumn{3}{|l|}{ Age (years) } \\
\hline 20 and under & 995 & 32.2 \\
\hline Between 20-35 & 1,292 & 41.8 \\
\hline Between 36-50 & 581 & 18.8 \\
\hline Between 51-64 & 140 & 4.5 \\
\hline 65 and over & 86 & 2.8 \\
\hline \multicolumn{3}{|l|}{ Gender } \\
\hline Male & 1,085 & 35.1 \\
\hline Female & 2,009 & 64.9 \\
\hline \multicolumn{3}{|l|}{ Marital status } \\
\hline Married & 1084 & 35.0 \\
\hline Single & 2,010 & 65.0 \\
\hline \multicolumn{3}{|l|}{ Education status } \\
\hline Middle school and lower & 458 & 14.8 \\
\hline High school & 1,533 & 49.5 \\
\hline University & 929 & 30.0 \\
\hline Postgraduate & 174 & 5.6 \\
\hline \multicolumn{3}{|l|}{ Region } \\
\hline Mediterranean region & 134 & 4.3 \\
\hline Eastern anatolia region & 382 & 12.3 \\
\hline Aegean region & 192 & 6.2 \\
\hline Southeastern anatolia region & 139 & 4.5 \\
\hline Central anatolia region & 225 & 7.3 \\
\hline Black sea region & 298 & 9.6 \\
\hline Marmara region & 1,724 & 55.7 \\
\hline \multicolumn{3}{|l|}{ Residential area } \\
\hline Greater city area & 1,886 & 61.0 \\
\hline Downtown & 562 & 18.2 \\
\hline District center & 493 & 15.9 \\
\hline Village/Town & 153 & 4.9 \\
\hline \multicolumn{3}{|l|}{ Chronic illness } \\
\hline No & 2,703 & 87.4 \\
\hline Yes & 391 & 12.6 \\
\hline
\end{tabular}


Table 2. Comparison of the demographic characteristics of the participants in terms of their knowledge of protection from COVID-19 disease

\begin{tabular}{|c|c|c|c|}
\hline Age group (years) & & $\mathbf{F}$ & p \\
\hline 20 and under & $23.07 \pm 2.78$ & \multirow{5}{*}{248.672} & \multirow{5}{*}{$<0.001^{*}$} \\
\hline Between 20-35 & $22.86 \pm 2.95$ & & \\
\hline Between 36-50 & $22.83 \pm 2.46$ & & \\
\hline Between 51-64 & $22.41 \pm 2.77$ & & \\
\hline 65 and over & $11.43 \pm 11.34$ & & \\
\hline Gender & & $\mathrm{T}$ & $p$ \\
\hline Male & $21.54 \pm 5.47$ & \multirow{2}{*}{-9.222} & \multirow{2}{*}{$<0.001^{*}$} \\
\hline Married & $23.15 \pm 2.37$ & & \\
\hline Marital status & & $\mathrm{T}$ & $p$ \\
\hline The married & $21.91 \pm 5.07$ & \multirow{2}{*}{$-6,262$} & \multirow{2}{*}{$<0.001^{*}$} \\
\hline Single & $22.95 \pm 2.90$ & & \\
\hline Education status & & $\mathrm{F}$ & $p$ \\
\hline Middle school and lower & $22.19 \pm 3.79$ & \multirow{4}{*}{9,141} & \multirow{4}{*}{$<0.001^{*}$} \\
\hline High school & $22.37 \pm 4.59$ & & \\
\hline University & $23.03 \pm 2.43$ & & \\
\hline Postgraduate & $23.22 \pm 2.23$ & & \\
\hline Residential area & & $\mathrm{F}$ & $p$ \\
\hline Greater city area & $23.01 \pm 2.74$ & \multirow{4}{*}{50,206} & \multirow{4}{*}{$<0.001^{*}$} \\
\hline Downtown & $20.84 \pm 6.74$ & & \\
\hline District center & $22.89 \pm 2.34$ & & \\
\hline Village/Town & $22.83 \pm 2.61$ & & \\
\hline Chronic illness & & $\mathrm{T}$ & $p$ \\
\hline No & $22.54 \pm 3.98$ & \multirow{2}{*}{$-2,299$} & \multirow{2}{*}{0.022} \\
\hline Yes & $22.90 \pm 2.63$ & & \\
\hline${ }^{*} \mathrm{p}<0.05$, COVID-19: Corona & sease-2019 & & \\
\hline
\end{tabular}

compared to females, for married participants compared to single participants, and for participants living in city centers compared to participants living in other areas $(p<0.001)$. On the other hand, it was determined that participants with bachelor's and postgraduate education levels had higher scores than participants who had other levels of education $(p<0.001)$. No significant difference was found in knowledge level scores in terms of the chronic disease status category $(p=0.022)$.

The participants' demographic characteristics were compared regarding their scores for level of compliance with preventive measures taken against the COVID-19 disease by using independent samples t-test and one-way analysis of variance (Table 3), and it was determined that scores were higher for participants aged 36-50 years compared to those aged $20-35$ years $(p=0.001)$, for female participants compared to males $(p<0.001)$, for married participants compared to

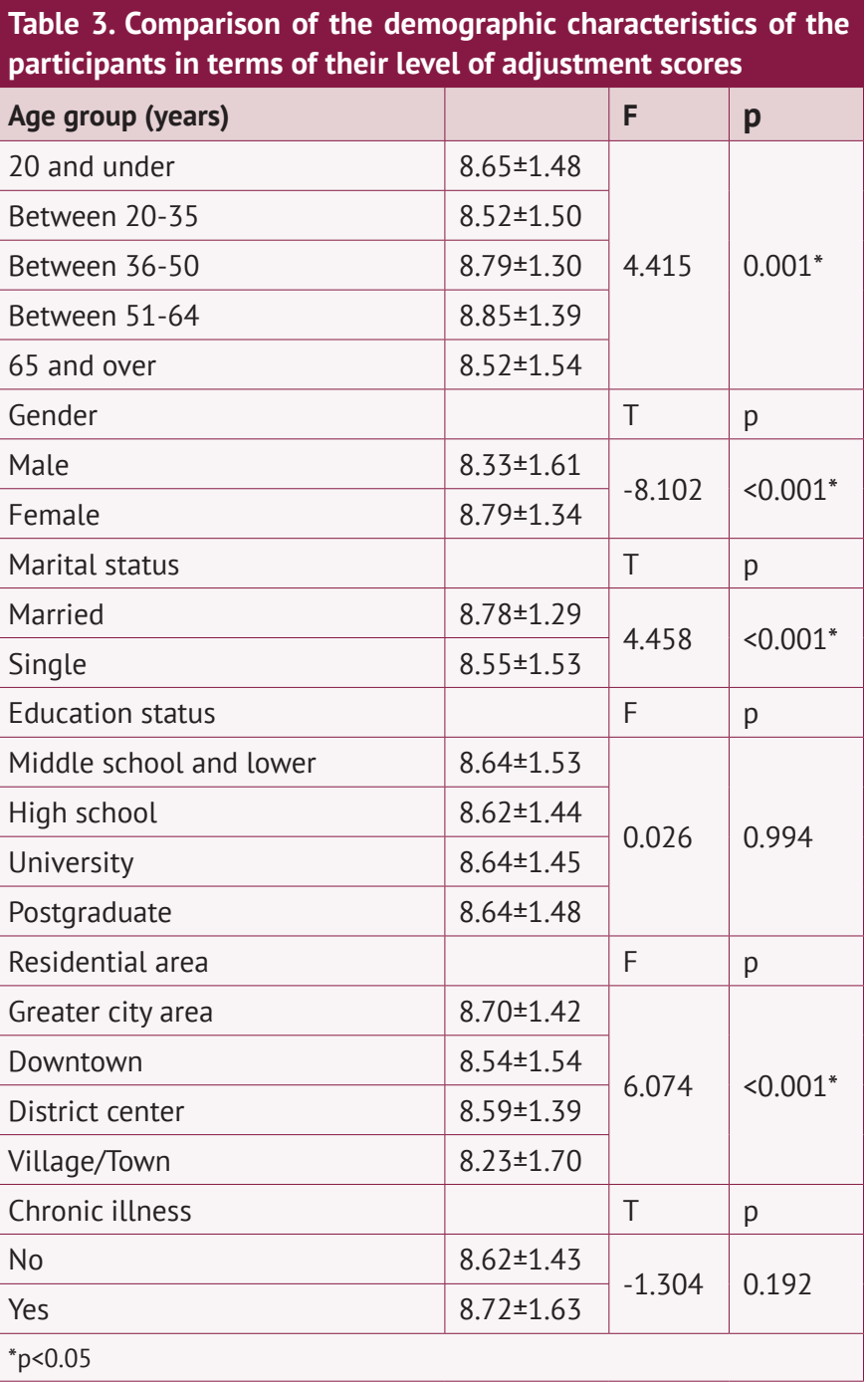

single participants $(p<0.001)$, and for participants living in city centers compared to those living in villages and towns $(p<0.001)$. No significant difference was found in compliance level scores in terms of the chronic disease status $(p=0.192)$ or the education status $(p=0.994)$ categories.

\section{Discussion}

In Turkey, notifications about the pandemic began before the pandemic had arrived in the country and continue to be made using audio and visual media and digital platforms. According to the data of the Supreme Board of Radio and Television, television is mostly watched by individuals aged 45 years and over, and it is stated that people aged 50 years and over find health-related television programs to be an important source of information $(14,15)$. According to the TUIK research into household information technology use, while the rate of computer usage during the last three months by people aged 65 years and over was $8.5 \%$, the internet 
usage rate was $19.8 \%$. The fact that knowledge levels related to protection from the disease were lowest in the group aged 65 years and over may be due to the limitations such as inability to access up-to-date information by individuals in this age group. According to the January 2020 report by We Are Social and Hootsuite, in terms of social media usage rates, this group represents the smallest population, with the rate of $1 \%$ in women and $1.8 \%$ in men (16). While social media and other internet tools such as search engines have an inquiry feature, television programs and printed magazines follow a certain flow. In people aged 65 years and over, besides adapting to new information, carrying out new behaviors other than the habits they have acquired may also be difficult. When memory, sight, and hearing faculties are also taken into consideration, this sensitive group may also require repetition of information in audio and visual publications, or retention of this information by their family. In a study examining knowledge and attitudes related to protection from the COVID-19 disease by the Egyptian public, it was similarly reported that knowledge levels in individuals aged 65 years and over were low. It should be recommended that for this age group, more accessible communication tools are used, or that their families behave more responsibly (17).

The volunteers included in this study, in which people's knowledge and compliance levels related to methods of protection from COVID-19 disease were evaluated, were predominantly made up of individuals aged 20-35 years who were female, single, and high school graduates, and who lived in the city. In terms of scores for levels of compliance with preventive measures taken against the disease, it was seen that participants aged $36-50$ years had higher scores than participants aged 20-35 years. This situation may be since people in this age group are still active in society, they have more health-related knowledge and experience due to age, and their health and social anxieties increase due to these experiences. Moreover, studies report that the knowledge that mortality is lower in young people decreases their compliance with preventive measures (18). In terms of the age variable, assuming that they are not in the risk group may make individuals think that compliance with preventive measures is unnecessary. According to the results of research examining the levels of compliance related to protection from COVID-19 disease by young participants and males, it was reported that these groups had lower scores than other participants $(19,20)$.

In the study by Pan et al. (21), it was stated that patients' mean age was 56 years and that while the rate of critical cases in diagnosed individuals aged $20-39$ years was $12.1 \%$, this rate increased to $41.3 \%$ in individuals aged over 80 years (21). Similarly, the mean age of patients included in the study by Li et al. (22) was 59 years. These data support the hypothesis that the prognosis of the disease becomes more severe with age and reveal that intense efforts are required to protect this sensitive group and to prevent the severity of the disease from worsening. In the literature, studies report that among the factors having a positive effect on the levels of compliance with preventive measures aiming at protection from COVID-19 disease are perceived risk, motivation, and high health-related anxiety levels $(19,22,23,24)$. Saurabh and Ranjan (25) determined that levels of knowledge and compliance with preventive measures related to protection from COVID-19 disease in India were low and argued that this situation could be improved by offering financial support for efforts to inform the public about the pandemic, and by enabling the public to access information sources (25).

Several studies that examine society's knowledge and attitude levels regarding the COVID-19 disease support the finding obtained in this study that female participants were in a better position than male participants concerning both knowledge and compliance levels related to protection against the disease $(20,26,27,28)$. The higher levels of compliance in women can be explained by their greater anxieties related to the disease. Indeed, Vesga-López et al. (29) stated that the probability of suffering from an anxiety disorder, which is a psychological illness, was greater in female individuals compared to male individuals (29). Anxiety can assist in avoiding situations that are dangerous to health (30). According to the research by Erdoğdu et al. (31), it was reported that women's anxiety levels towards the COVID-19 disease were higher than men's.

In several studies, it is reported that the Severe Acute Respiratory syndrome-Coronavirus-2, which causes the COVID-19 disease, is caught by both genders, but that mostly males contract the disease $(20,32,33,34)$. The reasons why men are more affected by the pandemic can be explained by the fact that men are more inclined towards risky behavior and more prone to chronic diseases, and that their smoking habits are more common $(6,20,21,35)$. The fact that the disease is more severe in males can be explained by several potential factors, such as the higher expression of the angiotensinconverting enzyme-2 (coronavirus receptors) in men than in women, and gender-based immunological differences and differences due to the $X$ chromosome. It is considered that a part of this difference is due to gender behaviors (lifestyle), that is, that rates of tobacco and alcohol use are higher in men than in women (36). Although it is known that the disease is more mortal in men, in this study, unfortunately, men's knowledge and compliance levels were found to be lower, concerning gender behaviors.

In terms of knowledge and compliance with preventive measures related to protection from the disease, the fact that in the "marital status" variable, single participants had 
greater protection knowledge but lower compliance levels than married participants suggests that they were unable to convert their knowledge into behavior. In a study examining knowledge and attitude levels related to the COVID-19 disease in the Chinese public, it was reported that single individuals' knowledge levels were lower (20).

The findings of the study reveal that in terms of education status in Turkey, as expected, participants with bachelor's and postgraduate education had better knowledge about protection from COVID-19 disease. Studies support this finding in the literature $(17,20,37)$. Due to reporting of information about the disease via official sources and effective warnings by healthcare authorities, the effective use of the internet, contract tracing and family practice implementations, protection knowledge scores of participants with bachelor's and postgraduate education were, as expected, higher than those of the others. However, levels of compliance with preventive measures did not differ from those of participants with other education levels.

Our data show that in Turkey, the knowledge levels of participants living in villages and towns were higher, whereas compliance levels of those living in city centers were higher.

\section{Addition 1. Questionnaire Used in the Research}

Please tick the "correct" column next to the items that you think as correct, and the "false" column next to the items that you think as incorrect.

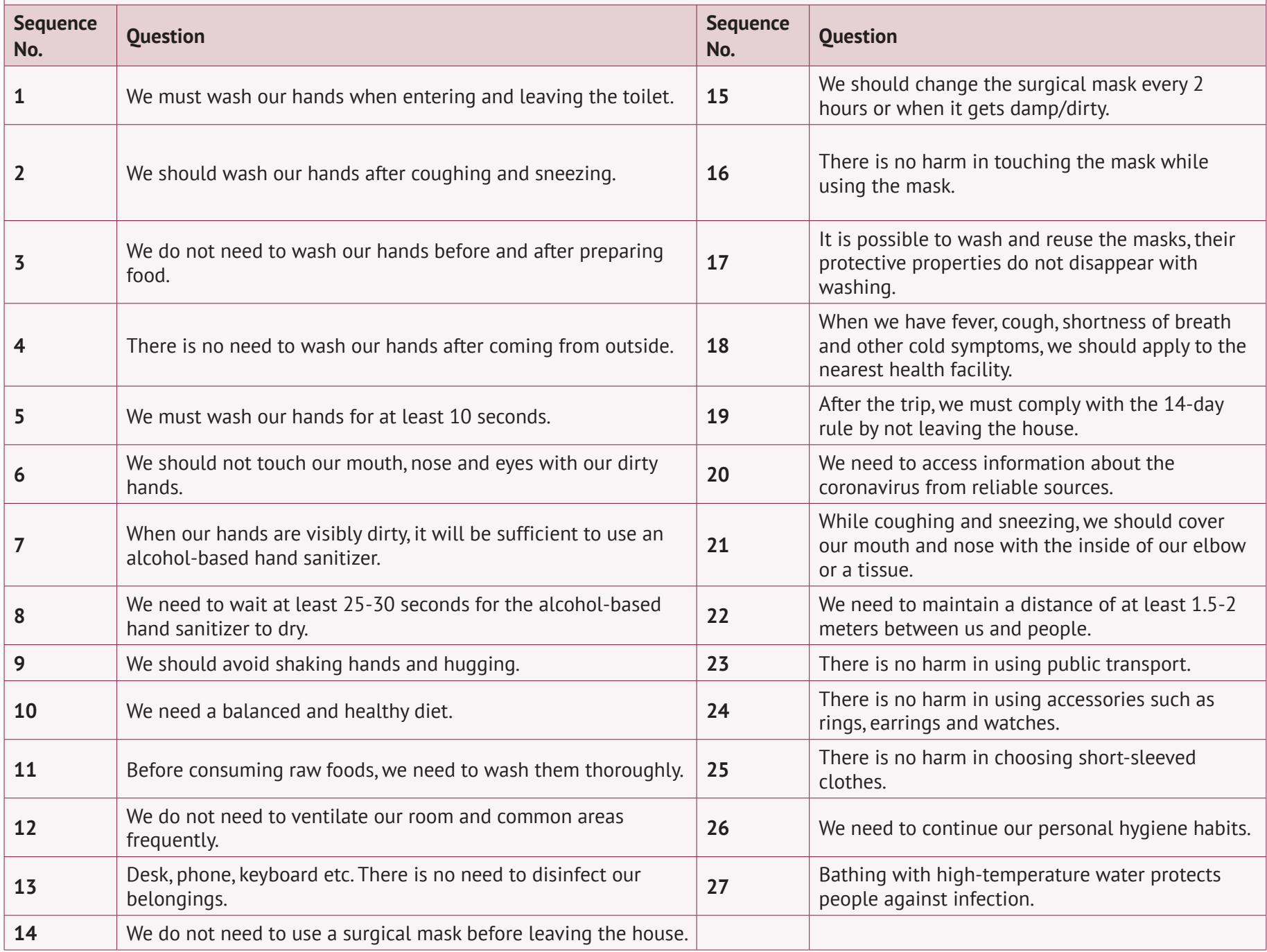

Rate your level of compliance with the measures related to COVID-19 from 1 to 10. (How much do you sleep within your means? For example, going out due to your commute doesn't mean you don't fit)

\begin{tabular}{|l|l|l|l|l|l|l|l|l|l|}
\hline 1 & 2 & 3 & 4 & 5 & 6 & 7 & 8 & 9 & 10 \\
\hline
\end{tabular}

COVID-19: Coronavirus disease-2019 
It is thought that the knowledge of participants living in city centers was affected by different sources of information and that the difference in compliance that was formed could be related to an increase in compliance with compulsory bans and restrictions in crowded areas. Some studies report that knowledge and compliance levels of individuals living in villages or towns related to COVID-19 disease are lower $(17,20)$. In the study by Wolf et al. $(18)$, it was stated that individuals, living in areas where transport to healthcare services was inadequate, believed that they would not catch the COVID-19 disease and that they felt unprepared for the pandemic (18). The fact that those residing in villages and towns had less compliance than those in other settlement areas can be associated with the unfounded confidence they felt to the effect that the pandemic would not reach the area where they lived. Moreover, these results that we obtained are significant in terms of revealing that the correlation between knowledge and compliance with preventive measures can change according to an area of settlement. It is seen that in Turkey, urbanization and marital status are important for the conversion of knowledge into behavior.

In several studies, it is reported that severe COVID-19 patients have additional chronic diseases (32). For this reason, those with chronic diseases must have correct knowledge regarding the protection and pay attention to preventive measures. According to the findings of this study, the presence of the chronic disease did not make a difference compared to those without chronic disease. In the study by Ergün et al. (38), however, levels of compliance with preventive measures were higher in participants who did not have a chronic disease. This situation may stem from the fact that due to protection facilities offered by the state (supply of medicine, communication with family practitioner, exemption from work), those with chronic diseases do not feel the need for extra precautions. Those with chronic diseases should be included as a target group in extra programs related to knowledge and compliance and should possess higher levels of knowledge and compliance than healthy individuals.

\section{Conclusion}

In conclusion, levels of knowledge related to protection from the COVID-19 disease were higher in participants who were below the age of 65 years, female, single, and university graduates, and who lived in villages or towns. On the other hand, levels of compliance with preventive measures aiming at protection from the disease were higher in participants who were aged between 36 and 50 years, female, and married, and who lived in the city center. The findings we have obtained reveal that there are differences in levels of knowledge and compliance in society and therefore, information needs to be repeated. It is stated that as people's knowledge levels related to the COVID-19 increase, they display more positive compliance with preventive measures. However, our findings reveal that in some groups in which knowledge levels were high, it could not always be inferred that their compliance levels were also high. It is seen that in Turkey,urbanization and marital status are important for the conversion of knowledge into behavior. Our results may serve as a guide for public health planners and healthcare administrators, especially by serving the purpose of determining groups whose levels of knowledge and compliance are low and of creating COVID-19 training and behavior programs for target groups.

\section{Ethics}

Ethics Committee Approval: Ethical approval was obtained from the Hamidiye Scientific Research Ethics Committee for the conduct of the study (date and number: 05 May 2020; 46418926-050.03.04).

Informed Consent: Informed consent for participating in the research was obtained.

Peer-review: Externally and internally peer-reviewed.

\section{Authorship Contributions}

Concept: Ş.N.K., N.Ş., C.Ö., Design: Ş.N.K., K.N.B., N.Ş., C.Ö., Data Collection or Processing: S..N.K., K.N.B., N.Ş., C.Ö., Analysis or Interpretation: Ş.N.K., K.N.B., N.Ş., Literature Search: Ş.N.K., K.N.B., N.Ş., C.Ö., Writing: Ş.N.K., N.Ş., C.Ö.

Conflict of Interest: No conflict of interest was declared by the authors.

Financial Disclosure: The authors declared that this study received no financial support.

\section{References}

1. WHO. Director-General's opening remarks at the media briefing on COVID-19 - 11 March 2020. Last Accessed Date: 16.11.2020. Available from: $\quad$ https://www.who.int/director-general/speeches/detail/whodirector-general-s-opening-remarks-at-the-media-briefing-on-covid-1911-march-2020. [Crossref]

2. Li W, Yang Y, Liu ZH, Zhao YJ, Zhang Q, Zhang L, et al. Progression of mental health services during the COVID-19 outbreak in China. Int J Biol Sci. 2020;16:1732-1738. [Crossref]

3. Koca F. Promotion of scientific research on COVID-19 in Turkey. Lancet. 2020;396:25-26. [Crossref]

4. Karcıoğlu Ö. COVID-19: Its epidemiology and course in the world. Journal of ADEM. 2020;1:55-71. [Crossref]

5. Cascella M, Rajnik M, Aleem A, Dulebohn SC, Di Napoli R. Features, Evaluation, and Treatment of Coronavirus (COVID-19). 2021 Jul 30. In: StatPearls [Internet]. Treasure Island (FL): StatPearls Publishing; 2021 Jan. [Crossref]

6. Rothan HA, Byrareddy SN. The epidemiology and pathogenesis of coronavirus disease (COVID-19) outbreak. J Autoimmun. 2020;109:102433. [Crossref]

7. Alıcılar HE, Güneş G, Col M. Assessment of awareness, attitudes and behaviors related to the COVID-19 pandemic in the community.ESTÜDAM Halk Sağlığı Dergisi. 2020;5:1-16. [Crossref] 
8. Khasawneh Al, Humeidan AA, Alsulaiman JW, Bloukh S, Ramadan M, AlShatanawi TN, et al. Medical students and COVID-19: Knowledge, attitudes, and precautionary measures. A descriptive study from Jordan. Front Public Heal. 2020;8:253. [Crossref]

9. Karcıoğlu 0 . What is coronaviruses, and how can we protect ourselves? Phnx Med J. 2020;2:66-71. [Crossref]

10. Republic of Turkey Ministry of Health, General Directorate of Public Health. COVID-19 Guide, 2020. Last Accessed Date: 02.12.2020. Available from: https://covid19.saglik.gov.tr/TR-66301/covid-19-rehberi.html. [Crossref]

11. Turkish Statistical Institute. Household Information Technology Usage Survey.Last Accessed Date:01.12.2020.Available form:https://turkstatweb. tuik.gov.tr/PreHaberBultenleri.do?id=33679-2020-33679;2020. [Crossref]

12. Turkey Statistical Institute Address Based Population Registration System Results. Last Accessed Date: 01.12.2020. Available form: https://turkstatweb.tuik.gov.tr/ PreHaberBultenleri.do; jsessionid= gsZdgCOப81t8wp 41F9JXQJJgLwlkOfJySj2 qDkyMzbQZLFvvcLg! 581326018?id=30709. [Crossref]

13. Özdemir K. Modern research methods. Eskisehir: Kaan Bookstore; 2003. [Crossref]

14. RTUK | Radio and Television Supreme Council. Television Watching Trends Research. Last Accessed Date: 10.10.2020. Available form: https://www. rtuk.gov.tr/rtukkamuoyuarastirmalari/3890/5776/televizyon_izleme_ egilimleri_arastirmasi_2018.html; 2018. [Crossref]

15. Koçak A, Bulduklu Y. Health communication: motivation of elderly people to watch health programs broadcasted on television. Selcuk Communication. 2010;6:5-17. [Crossref]

16. Bayrak H. 2020 Turkey use of the Internet and social media statistics, Dijilopedi. Last Accessed Date: 15.10.2020. Available form: https:// dijilopedi.com/2020-turkiye-internet-kullanimi-ve-sosyal-medyaistatistikleri/; 2020. [Crossref]

17. Abdelhafiz AS, Mohammed Z, Ibrahim ME, Ziady HH,Alorabi M, Ayyad M, et al. Knowledge, perceptions, and attitude of egyptians towards the novel Coronavirus Disease (COVID-19). J Community Health.2020;45:881-890. [Crossref]

18. Wolf MS, Serper M, Opsasnick L, O’Conor RM, Curtis L, Benavente JY, et al. Awareness, attitudes, and actions related to COVID-19 among adults with chronic conditions at the onset of the U.S. outbreak: A Cross-sectional Survey. Ann Intern Med. 2020;173:100-109. [Crossref]

19. Solomou I, Constantinidou F. Prevalence and predictors of anxiety and depression symptoms during the COVID-19 pandemic and compliance with precautionary measures: Age and sex matter. Int J Environ Res Public Health. 2020;17:4924. [Crossref]

20. Zhong BL, Luo W, Li HM,Zhang QQ, Liu XG, Li WT,et al. Knowledge, attitudes, and practices towards COVID-19 among chinese residents during the rapid rise period of the COVID-19 outbreak: a quick online cross-sectional survey. Int J Biol Sci. 2020;16:1745-1752. [Crossref]

21. Pan A, Liu L, Wang C, Guo H, Hao X, Wang Q, et al. Association of public health Interventions with the Epidemiology of the COVID-19 Outbreak in Wuhan, China. JAMA. 2020;323:1915-1923. [Crossref]

22. Li X, Xu S, Yu M, Wang K, Tao Y, Zhou Y, et al. Risk factors for severity and mortality in adult COVID-19 inpatients in Wuhan. J Allergy Clin Immunol. 2020;146:110-118. [Crossref]
23. Allington D, Duffy B, Wessely S, Dhavan N, Rubin J. Health-protective behaviour, social media usage, and conspiracy belief during the COVID-19 public health emergency. Psychol Med. 2021;51:1769-1769. [Crossref]

24. Marinthe G,Brown G,Delouvée S,Jolley D. Looking out for myself: Exploring the relationship between conspiracy mentality, perceived personal risk, and COVID-19 prevention measures. Br J Health Psychol. 2020;25:957980. [Crossref]

25. Saurabh K, Ranjan S. Compliance and psychological ımpact of quarantine in children and adolescents due to COVID-19 pandemic. Indian J Pediatr. 2020;87:532-536. [Crossref]

26. Chen Y,Jin YL,Zhu ப,Fang ZM,Wu N,Du MX,et al.[The network investigation on knowledge, attitude and practice about Novel coronavirus pneumonia of the residents in Anhui Province.] Zhonghua Yu Fang Yi Xue Za Zhi. 2020;54:E004. doi: 10.3760/cma.j.issn.0253-9624.2020.0004. Online ahead of print. (Chinese) [Crossref]

27. Abir T, Kalimullah NA, Osuagwu UL, Yazdani DMNA, Mamun A Al, Husain $\mathrm{T}$, et al. Factors associated with the perception of risk and knowledge of contracting the SARS-CoV-2 among adults in Bangladesh: Analysis of online surveys. Int J Environ Res Public Health. 2020;17:1-17. [Crossref]

28. Alahdal H, Basingab F, Alotaibi R. An analytical study on the awareness, attitude and practice during the COVID-19 pandemic in Riyadh, Saudi Arabia.J Infect Public Health. 2020;13:1446-1452. [Crossref]

29. Vesga-López O, Schneier FR, Wang S, Heimberg RG, Liu SM, Hasin DS, et al. Gender differences in generalized anxiety disorder: results from the National Epidemiologic Survey on Alcohol and Related Conditions (NESARC).J Clin Psychiatry. 2008;69:1606-1616. [Crossref]

30. Karaer Karapıcak Ö, Aslan S, Utku C. Health anxiety in panic disorder, somatization disorder and hypochondriasis. JCBPR. 2012;1:43-51. [Crossref]

31. Erdoğdu Y, Koçoğlu F, Sevim C. An investigation of the psychosocial and demographic determinants of anxiety and hopelessness during COVID-19 pandemic.J Clin Psychiatry. 2020;23:24-37. (Turkish) [Crossref]

32. Sun P, Lu X, Xu C, Sun W, Pan B. Understanding of COVID-19 based on current evidence.J Med Virol. 2020;92:548-551. [Crossref]

33. Cai H. Sex difference and smoking predisposition in patients with COVID-19. Lancet Respir Med. 2020;8:e20. [Crossref]

34. Zu ZY, Di Jiang M, Xu PP, Chen W, Ni QQ, Lu GM, et al. Coronavirus disease 2019 (COVID-19): a perspective from China. Radiology. 2020;296:15-25. [Crossref]

35. Wang D, Hu B, Hu C, Zhu F, Liu X, Zhang J, et al. Clinical characteristics of 138 hospitalized patients with 2019 novel coronavirus-infected pneumonia in Wuhan, China. JAMA. 2020;323:1061-1069. [Crossref]

36. Bwire GM. Coronavirus: why men are more vulnerable to Covid-19 than women? SN Compr Clin Med. 2020;2:874-876. [Crossref]

37. Roy D, Tripathy S,Kar SK, Sharma N,Verma SK, Kaushal V.Study of knowledge, attitude, anxiety \& perceived mental healthcare need in Indian population during COVID-19 pandemic. Asian J Psychiatr. 2020;51:102083. [Crossref]

38. Ergün E, Ergün S, Çelebi I. Information on COVID-19, protection levels and affecting factors of emergency health care staff. JOPEHS. 2020;1:16-27. [Crossref] 